\title{
Genetic Diversity and Dissemination Pathways of Common Bean in Central Europe
}

\author{
Marko Maras ${ }^{1}$ and Jelka Šuštar-Vozlič \\ Agricultural Institute of Slovenia, Crop and Seed Science Department, Hacquetova ulica 17, 1000 \\ Ljubljana, Slovenia \\ Wolfgang Kainz \\ Agrarbiologie Linz, Wieningerstrasse 8, A-4021 Linz, Austria \\ Vladimir Meglič \\ Agricultural Institute of Slovenia, Hacquetova ulica 17, 1000 Ljubljana, Slovenia
}

\begin{abstract}
AdDitional INDEX words. Phaseolus vulgaris, landraces, gene pools, gene flow, SSRs
Abstract. Common bean (Phaseolus vulgaris L.) was introduced in Europe from both Mesoamerican and Andean centers of origin and has been cultivated in central Europe for centuries. The first objective of this study was to evaluate genetic diversity and the population structure of 167 accessions divided into four groups according to geographical origin (Slovenia and Austria) and time periods (historical and present) using 14 simple sequence repeat (SSR) markers. The second objective was to improve our understanding of the pathways of dissemination and the evolution of this species in central Europe. Great allelic polymorphism was detected in all four groups of examined accessions, indicating that Slovene and Austrian bean germplasm in the past possessed significant variation that has been well preserved until today. In factorial correspondence analysis, accessions from different groups clustered together indicating potential gene flow between countries. The uncovered diversity corresponded very well to the two recognized gene pools (Andean and Mesoamerican). The majority of accessions in every single group belonged to the Andean gene pool. Strong predominance of Andean genotypes classifies Slovenia among other Mediterranean countries, like Spain and Italy. The latter appears as a most probable source of first beans in Slovenia and Austria. We assume that in the beginning of the previous century after very tight relationships between Slovenia and Austria loosened, introgression of genotypes from western and northern European countries took place in Austria, which resulted in a very high proportion of Mesoamerican genotypes that we found in the present Austrian germplasm (44\%). Several putative hybrids between the Andean and Mesoamerican gene pools were detected in this study. Evolutionary significance, origin, and breeding potential of these recombinants are discussed here.
\end{abstract}

Common bean is by far the most widely consumed grain legume in the world (Singh, 2001). Domestication of common bean took place in two, already diverged ancestral wild gene pools distributed from northern Mexico to Colombia (Mesoamerican gene pool) and from southern Peru to northwestern Argentina (Andean gene pool) (Gepts et al., 1986; Khairallah et al., 1990; Koenig and Gepts, 1989). After the initial domestication phase, the common bean spread between Mesoamerica and South America and, after the European exploration of the Americas, to Europe and Africa (Gepts and Bliss, 1988; Gepts et al., 1986).

Common bean was introduced in Europe soon after Columbus' first voyage in 1492 (Zeven, 1997). These specimens were probably mainly of Mesoamerican origin because of the extensive commerce among Mexico, the Caribbean islands, and Spain (Rodino et al., 2006). In 1528 Pizzaro explored Peru, opening the possibility of introducing common bean from South America. Within Europe there was likely a quick distribution of common bean from the Iberian Peninsula as a curiosity (Zeven, 1997). No records of common bean earlier than 1543 have been found in northwestern European herbaria, suggesting

Received for publication 4 Jan. 2013. Accepted for publication 6 May 2013. The research was supported by grant J4-4126 from the Slovene Research Agency and by grant No. 168/01 from the SEE-ERA.NET.PLUS FP7 Regional Programme.

${ }^{1}$ Corresponding author. E-mail: marko.maras@kis.si. that the common bean was distributed in northwestern Europe after 1540 and in 1669 it was cultivated on a large scale (Zeven, 1997). Interestingly, none of the early records indicates the origin of the species (Gepts and Bliss, 1988).

Large variation of common bean evolved in Europe as a result of adaptation to new ecological and manmade conditions. Thousands of landraces, old and modern cultivars, are cultivated and maintained in gene banks across the European continent. Genetic diversity of the collections has been evaluated in numerous studies using different molecular markers. These include allozymes (Rodino et al., 2006; Santalla et al., 2002, 2010), phaseolin seed storage protein (Limongelli et al., 1996; Logozzo et al., 2007; Pérez-Vega et al., 2009; Piergiovanni et al., 2000; Rodino et al., 2003), amplified fragment length polymorphism [AFLP (Lioi et al., 2005; Šuštar-Vozlič et al., 2006; Svetleva et al., 2006)], random amplified polymorphic DNA (Marotti et al., 2007; Ocampo et al., 2005), and intersimple sequence repeat (Marotti et al., 2007; Sicard et al., 2005; Svetleva et al., 2006). Approximately 400 microsatellite or SSR markers have been developed for common bean (Blair et al., 2003; Gaitan-Solis et al., 2002; Metais et al., 2002; Yu et al., 1999) and used in construction of a genetic map (Blair et al., 2003; Yu et al., 2000), and evaluation of genetic variability (Angioi et al., 2009, 2010; Pérez-Vega et al., 2009; Sicard et al., 2005). Presently, SSRs are the markers of choice to evaluate genetic diversity in plants mainly as a result of high polymorphism presented and the facility interpreting results. 
In the study reported here, the organization of genetic diversity in common bean from Austria and Slovenia was examined using SSR markers. Austria and Slovenia are neighboring countries located in the southern part of central Europe. They belong to different ethnolinguistic groups, Germanic and Slavic, but they were part of the same political integration for several centuries in the previous millennium. Both historical and present landraces were examined in this study providing a rare and invaluable opportunity to evaluate the diversification process in common bean in a timeline and limited geographic area. The second objective of this study was to indicate the historical introduction routes of common bean in central Europe using the data obtained in this study and the data available in scientific literature.

\section{Materials and Methods}

Plant material. A total of 403 individuals, representing 167 different common bean accessions, were included in this study (Table 1). These accessions included 58 landraces represented by 196 individuals from the new and 49 landraces (93 individuals) from the 50-year-old common bean collection at the Agricultural Institute of Slovenia (new Slovene accessions and old Slovene accessions, respectively), whereas 27 landraces ( 81 individuals) originated from the new and 33 landraces (33 individuals) from the 200-year-old common bean collection at Agrarbiologie Linz, Austria (new Austrian accessions and old Austrian accessions, respectively).

Both the group of Austrian and the group of Slovene old accessions as well as 42 new Slovene accessions were already examined by Maras et al. (2006) using SSR markers. Moreover, a set of 27 new Slovene accessions were studied previously by Šuštar-Vozlič et al. (2006) using AFLP markers and phaseolin seed storage protein (all 27 accessions, except accession PHA374). This set of 27 new Slovene accessions includes also 16 accessions, which have not been analyzed yet by SSR markers (Table 1).

DNA Extraction. Each studied individual represents $\mathrm{s}$ single seed from which the total DNA was extracted using a GenElute Plant Genomic DNA Miniprep Kit (Sigma-Aldrich, St. Louis, MO). DNA was extracted from only one seed of old Austrian and the majority of old Slovene accessions because seeds of these ancient accessions are scarce and non-viable. Embryos from single seeds were isolated and ground into fine powder in liquid nitrogen. DNA was then extracted following the manufacturer's instructions and stored at $-20{ }^{\circ} \mathrm{C}$. Integrity and quality of DNA were evaluated by electrophoresis on $0.8 \%$ agarose gels. Concentrations of DNA samples were determined with a fluorometer (TKO-100; Hoefer, Holliston, MA).

Molecular analyses. Fourteen SSR loci developed by Gaitan-Solis et al. (2002) and Metais et al. (2002) were analyzed (Table 2). Amplification reactions were performed with the thermocycler (Gene Amp PCR system 9700; Life Technologies, Grand Island, NY) in a $10-\mu \mathrm{L}$ reaction mixture. Each reaction contained $1 \times$ polymerase chain reaction $(\mathrm{PCR})$ buffer, $2 \mathrm{~mm} \mathrm{MgCl}_{2}, 200 \mu \mathrm{M}$ dNTPs, $0.25 \mu \mathrm{M}$ unlabeled right primer, $0.25 \mu \mathrm{M}$ labeled left primer, $0.5 \mathrm{U}$ of AmpliTaq DNA Polymerase (Life Technologies), and $20 \mathrm{ng}$ of genomic DNA. Loci were amplified using a profile of initial denaturation at $95^{\circ} \mathrm{C}$ for $3 \mathrm{~min}$ followed by 30 cycles of strand denaturation at $94{ }^{\circ} \mathrm{C}$ for $30 \mathrm{~s}$, primer annealing at 47 to $62^{\circ} \mathrm{C}$ for $30 \mathrm{~s}$, DNA extension at $72{ }^{\circ} \mathrm{C}$ for $30 \mathrm{~s}$, and final extension at $72{ }^{\circ} \mathrm{C}$ for
$4 \mathrm{~min}$. Fluorescently labeled PCR products were mixed with formamide and internal size standard (GeneScan-350; Life Technologies) and genotyped on the ABI Prism 310 Genetic Analyzer (Life Technologies) using GeneScan Analysis Software 2.1 (Life Technologies).

DAta ANALyses. The number of specific and shared alleles in the four groups of accessions were counted for each SSR locus (Table 2).

Total genetic diversity was partitioned among and within four groups of accessions by carrying out a hierarchical analysis of molecular variance (AMOVA). The Fst was calculated and significance testing was performed using the permutational procedures offered in GenAlEx 6 (Peakall and Smouse, 2006). The same procedure was used then in the assessment of all possible pairwise comparisons among four groups of accessions and groupings according to cultivation period and geographical origin.

To illustrate the distribution of genetic variability across individuals, a factorial correspondence analysis (FCA) as implemented in Genetix 4.02 (Belkhir et al., 2001) was carried out. The principle of FCA is based on transformation of genetic data into a contingency table (samples $\times$ alleles), in which each sample is described by the allele presence. The $\chi^{2}$ distance is used to measure the relatedness between any two samples in the multidimensional space. The resulting factorial axes that optimize the differences between the analyzed individuals are ordered according to their values. The first axis corresponds to the largest value and explains the most general pattern or structure contained in the data set (Guinand, 1996).

Using SSR data, we applied a Bayesian model-based clustering algorithm implemented in Structure 2.1 (Pritchard et al., 2000) to verify the assignment of the accessions according to the gene pool of origin. Because Structure overestimates the number of clusters when examining inbred individuals, it is more reliable to choose the number of clusters based on prior information (Pritchard and Wen, 2004). We set the number of clusters $(\mathrm{K})$ to two, owing to prior knowledge of the organization of genetic diversity from FCA. Five runs of Structure were performed, setting the burn-in time to 80,000 and replication number to 200,000 .

\section{Results}

A total of 147 alleles were found across the full set of individuals. The average number of alleles per SSR was 10.5 and ranged from four alleles for ATA5 to 16 alleles for ATA13 and GATS91 (Table 2). Other SSRs showing a high number of alleles were ATA6 and BM170 each with 12 alleles and ATA16, BM183, and BM210 with 14 alleles. The size range between smallest and largest allele observed for a given SSR varied from $12 \mathrm{bp}$ (ATA7) to $54 \mathrm{bp}$ (ATA13).

Of the total data set, the groups of new and old Slovene accessions were the most variable with an average of 8.2 and 6.7 alleles per primer pair (Table 2). The smallest number of alleles among the four groups was found in old Austrian accessions (84), but this group was the second most abundant concerning group-specific alleles (10).

With respect to geographical origin of accessions, 129 out of a total of 147 alleles were found in 107 Slovene accessions (289 individuals), including 39 group-specific alleles, whereas 108 alleles were found in 60 Austrian accessions (114 individuals), of which 18 were group-specific. 
Table 1. New and old Slovene and Austrian common bean accessions assessed for variability at 14 simple sequence repeat loci.

\begin{tabular}{|c|c|c|c|c|c|c|c|c|}
\hline \multicolumn{5}{|c|}{ New Slovene accessions } & \multicolumn{4}{|c|}{ Old Slovene accessions } \\
\hline Serial no. & Accession & Individuals studied (no.) & Gene pool ${ }^{\mathrm{z}}$ & Phaseolin type & Serial no. & Accession & Individuals studied (no.) & Gene pool \\
\hline 1 & PHA7 & 5 & $\mathrm{M}^{\mathrm{M}, \mathrm{M}}$ & $\mathrm{S}$ & 59 & S1 & 5 & $\mathrm{~A}^{\mathrm{A},-}$ \\
\hline 2 & PHA11 & 3 & $\mathrm{~A}^{-, \mathrm{A}}$ & $\mathrm{C}$ & 60 & S2 & 1 & $\mathrm{~A}^{\mathrm{A},-}$ \\
\hline 3 & PHA15 & 5 & $\mathrm{~A}^{\mathrm{A}, \mathrm{A}}$ & $\mathrm{C}$ & 61 & S3 & 1 & $\mathrm{~A}^{\mathrm{A},-}$ \\
\hline 4 & PHA28 & 1 & $\mathrm{~A}^{\mathrm{A},-}$ & & 62 & S4 & 1 & $\mathrm{~A}^{\mathrm{A},-}$ \\
\hline 5 & PHA29 & 5 & $\mathrm{~A}^{\mathrm{A}, \mathrm{A}}$ & $\mathrm{C}$ & 63 & S5 & 1 & $\mathrm{~A}^{\mathrm{A},-}$ \\
\hline 6 & PHA59 & 3 & $\mathrm{M}^{-, \mathrm{M}}$ & $\mathrm{C}$ & 64 & S6 & 1 & $\mathrm{~A}^{\mathrm{A},-}$ \\
\hline 7 & PHA65 & 1 & $\mathrm{~A}^{\mathrm{A},-}$ & & 65 & S7 & 1 & $\mathrm{M}^{\mathrm{A},-}$ \\
\hline 8 & PHA152 & 5 & $\mathrm{~A}^{\mathrm{A},-}$ & & 66 & S8 & 1 & $\mathrm{~A}^{\mathrm{A},-}$ \\
\hline 9 & PHA153 & 5 & $\mathrm{~A}^{\mathrm{A}, \mathrm{A}}$ & $\mathrm{C}$ & 67 & S9 & 1 & $\mathrm{~A}^{\mathrm{A},-}$ \\
\hline 10 & PHA192 & 1 & $\mathrm{~A}^{\mathrm{A},-}$ & & 68 & S10 & 5 & $\mathrm{~A}^{\mathrm{A},-}$ \\
\hline 11 & PHA263 & 5 & $\mathrm{~A}^{\mathrm{A},-}$ & & 69 & S12 & 1 & $\mathrm{~A}^{\mathrm{A},-}$ \\
\hline 12 & PHA280 & 1 & $\mathrm{~A}^{\mathrm{A},-}$ & & 70 & S13 & 1 & $\mathrm{~A}^{\mathrm{A},-}$ \\
\hline 13 & PHA283 & 5 & $\mathrm{~A}^{\mathrm{A},-}$ & & 71 & S14 & 1 & $\mathrm{~A}^{\mathrm{A},-}$ \\
\hline 14 & PHA301 & 1 & $\mathrm{~A}^{\mathrm{A},-}$ & & 72 & S15 & 1 & $\mathrm{~A}^{\mathrm{A},-}$ \\
\hline 15 & PHA307 & 3 & $\mathrm{~A}^{-, \mathrm{A}}$ & $\mathrm{T}$ & 73 & S16 & 1 & $\mathrm{~A}^{\mathrm{A},-}$ \\
\hline 16 & PHA309 & 5 & $\mathrm{~A}^{\mathrm{A}, \mathrm{A}}$ & $\mathrm{T}$ & 74 & S17 & 5 & $\mathrm{~A}^{\mathrm{A},-}$ \\
\hline 17 & PHA316 & 5 & $\mathrm{M}^{\mathrm{M}, \mathrm{M}}$ & $\mathrm{S}$ & 75 & S18 & 1 & $\mathrm{~A}^{\mathrm{A},-}$ \\
\hline 18 & PHA346 & 3 & $\mathrm{~A}^{-, \mathrm{A}}$ & $\mathrm{T}$ & 76 & S19 & 1 & $\mathrm{M}^{\mathrm{M},-}$ \\
\hline 19 & PHA358 & 5 & $\mathrm{~A}^{\mathrm{A}, \mathrm{A}}$ & $\mathrm{T}$ & 77 & S20 & 1 & $\mathrm{~A}^{\mathrm{A},-}$ \\
\hline 20 & PHA363 & 5 & $\mathrm{~A}^{\mathrm{A}, \mathrm{A}}$ & $\mathrm{T}$ & 78 & $\mathrm{~S} 21$ & 1 & $\mathrm{~A}^{\mathrm{A},-}$ \\
\hline 21 & PHA374 & 1 & $\mathrm{~A}^{\mathrm{A}, \mathrm{A}}$ & & 79 & $\mathrm{~S} 22$ & 1 & $\mathrm{~A}^{\mathrm{A},-}$ \\
\hline 22 & PHA386 & 3 & $\mathrm{~A}^{-, \mathrm{A}}$ & $\mathrm{T}$ & 80 & $\mathrm{~S} 23$ & 1 & $\mathrm{M}^{\mathrm{M},-}$ \\
\hline 23 & PHA388 & 3 & $\mathrm{~A}^{-, \mathrm{A}}$ & $\mathrm{T}$ & 81 & $\mathrm{~S} 24$ & 1 & $\mathrm{~A}^{\mathrm{A},-}$ \\
\hline 24 & PHA413 & 1 & $\mathrm{~A}^{\mathrm{A},-}$ & & 82 & $\mathrm{~S} 25$ & 1 & $\mathrm{~A}^{\mathrm{A},-}$ \\
\hline 25 & PHA418 & 3 & $\mathrm{~A}^{-, \mathrm{A}}$ & $\mathrm{T}$ & 83 & S26 & 5 & $\mathrm{~A}^{\mathrm{A},-}$ \\
\hline 26 & PHA423 & 3 & $A^{-, A}$ & $\mathrm{~T}$ & 84 & $\mathrm{~S} 27$ & 1 & $\mathrm{M}^{\mathrm{M},-}$ \\
\hline 27 & PHA430 & 5 & $\mathrm{~A}^{\mathrm{A},-}$ & & 85 & S28 & 1 & $\mathrm{~A}^{\mathrm{A},-}$ \\
\hline 28 & PHA432 & 1 & $\mathrm{~A}^{\mathrm{A},-}$ & & 86 & S29 & 1 & $\mathrm{~A}^{\mathrm{A},-}$ \\
\hline 29 & PHA438 & 5 & $\mathrm{~A}^{\mathrm{A}, \mathrm{A}}$ & $\mathrm{C}$ & 87 & $\mathrm{~S} 30$ & 5 & $\mathrm{~A}^{\mathrm{A},-}$ \\
\hline 30 & PHA452 & 3 & $\mathrm{~A}^{-, \mathrm{A}}$ & $\mathrm{C}$ & 88 & $\mathrm{~S} 31$ & 1 & $\mathrm{~A}^{\mathrm{A},-}$ \\
\hline 31 & PHA498 & 3 & $\mathrm{~A}^{-, \mathrm{A}}$ & $\mathrm{T}$ & 89 & $\mathrm{~S} 32$ & 1 & $\mathrm{~A}^{\mathrm{A},-}$ \\
\hline 32 & PHA505 & 1 & $\mathrm{~A}^{\mathrm{A},-}$ & & 90 & S33 & 1 & $\mathrm{~A}^{\mathrm{A},-}$ \\
\hline 33 & PHA609 & 5 & $\mathrm{~A}^{\mathrm{A},-}$ & & 91 & S34 & 1 & $\mathrm{M}^{\mathrm{A},-}$ \\
\hline 34 & PHA639 & 3 & $\mathrm{~A}^{-, \mathrm{A}}$ & $\mathrm{C}$ & 92 & $\mathrm{~S} 35$ & 1 & $\mathrm{~A}^{\mathrm{A},-}$ \\
\hline 35 & PHA642 & 1 & $\mathrm{~A}^{\mathrm{A}, \mathrm{A}}$ & $\mathrm{C}$ & 93 & S36 & 5 & $\mathrm{~A}^{\mathrm{A},-}$ \\
\hline 36 & PHA643 & 1 & $\mathrm{M}^{\mathrm{M},-}$ & & 94 & S37 & 1 & $\mathrm{~A}^{\mathrm{A},-}$ \\
\hline 37 & PHA669 & 5 & $\mathrm{~A}^{\mathrm{A},-}$ & & 95 & S38 & 1 & $\mathrm{~A}^{\mathrm{A},-}$ \\
\hline 38 & PHA717 & 3 & $\mathrm{M}^{-, \mathrm{M}}$ & $\mathrm{S}$ & 96 & S39 & 1 & $\mathrm{~A}^{\mathrm{A},-}$ \\
\hline 39 & PHA729 & 5 & $\mathrm{~A}^{\mathrm{A},-}$ & & 97 & $\mathrm{~S} 40$ & 1 & $\mathrm{~A}^{\mathrm{A},-}$ \\
\hline 40 & PHA731 & 5 & $\mathrm{~A}^{\mathrm{A},-}$ & & 98 & S41 & 5 & $\mathrm{~A}^{\mathrm{A},-}$ \\
\hline 41 & PHA732 & 5 & $\mathrm{~A}^{\mathrm{A},-}$ & & 99 & S42 & 1 & $\mathrm{~A}^{\mathrm{A},-}$ \\
\hline 42 & PHA735 & 5 & $\mathrm{~A}^{\mathrm{A},-}$ & & 100 & S43 & 5 & $\mathrm{~A}^{\mathrm{A},-}$ \\
\hline 43 & PHA739 & 5 & $\mathrm{~A}^{\mathrm{A},-}$ & & 101 & S44 & 5 & $\mathrm{~A}^{\mathrm{A},-}$ \\
\hline 44 & PHA740 & 5 & $\mathrm{~A}^{\mathrm{A},-}$ & & 102 & S45 & 1 & $\mathrm{~A}^{\mathrm{A},-}$ \\
\hline 45 & PHA741 & 5 & $\mathrm{~A}^{\mathrm{A},-}$ & & 103 & S46 & 1 & $\mathrm{~A}^{\mathrm{A},-}$ \\
\hline 46 & PHA742 & 5 & $\mathrm{~A}^{\mathrm{A},-}$ & & 104 & S47 & 5 & $\mathrm{~A}^{\mathrm{A},-}$ \\
\hline 47 & PHA750 & 5 & $\mathrm{~A}^{\mathrm{A},-}$ & & 105 & S48 & 5 & $\mathrm{~A}^{\mathrm{A},-}$ \\
\hline 48 & PHA759 & 5 & $\mathrm{~A}^{\mathrm{A},-}$ & & 106 & S49 & 1 & $\mathrm{~A}^{\mathrm{A},-}$ \\
\hline 49 & PHA764 & 5 & $\mathrm{~A}^{\mathrm{A},-}$ & & 107 & $\mathrm{~S} 50$ & 1 & $\mathrm{~A}^{\mathrm{A},-}$ \\
\hline 50 & PHA777 & 3 & $A^{-, A}$ & $\mathrm{C}$ & & & & \\
\hline 51 & PHA802 & 1 & $\mathrm{~A}^{\mathrm{A},-}$ & & & & & \\
\hline 52 & PHA819 & 1 & $\mathrm{~A}^{\mathrm{A},-}$ & & & & & \\
\hline 53 & PHA834 & 1 & $\mathrm{~A}^{\mathrm{A},-}$ & & & & & \\
\hline 54 & PHA913 & 1 & $\mathrm{~A}^{\mathrm{A},-}$ & & & & & \\
\hline 55 & PHA950 & 3 & $A^{-, A}$ & $\mathrm{C}$ & & & & \\
\hline 56 & PHA954 & 5 & $A^{-, A}$ & $\mathrm{C}$ & & & & \\
\hline 57 & PHA973 & 3 & $A^{-, A}$ & $\mathrm{~T}$ & & & & \\
\hline 58 & PHA1011 & 1 & $\mathrm{~A}^{\mathrm{A},-}$ & & & & & \\
\hline
\end{tabular}


Table 1. Continued.

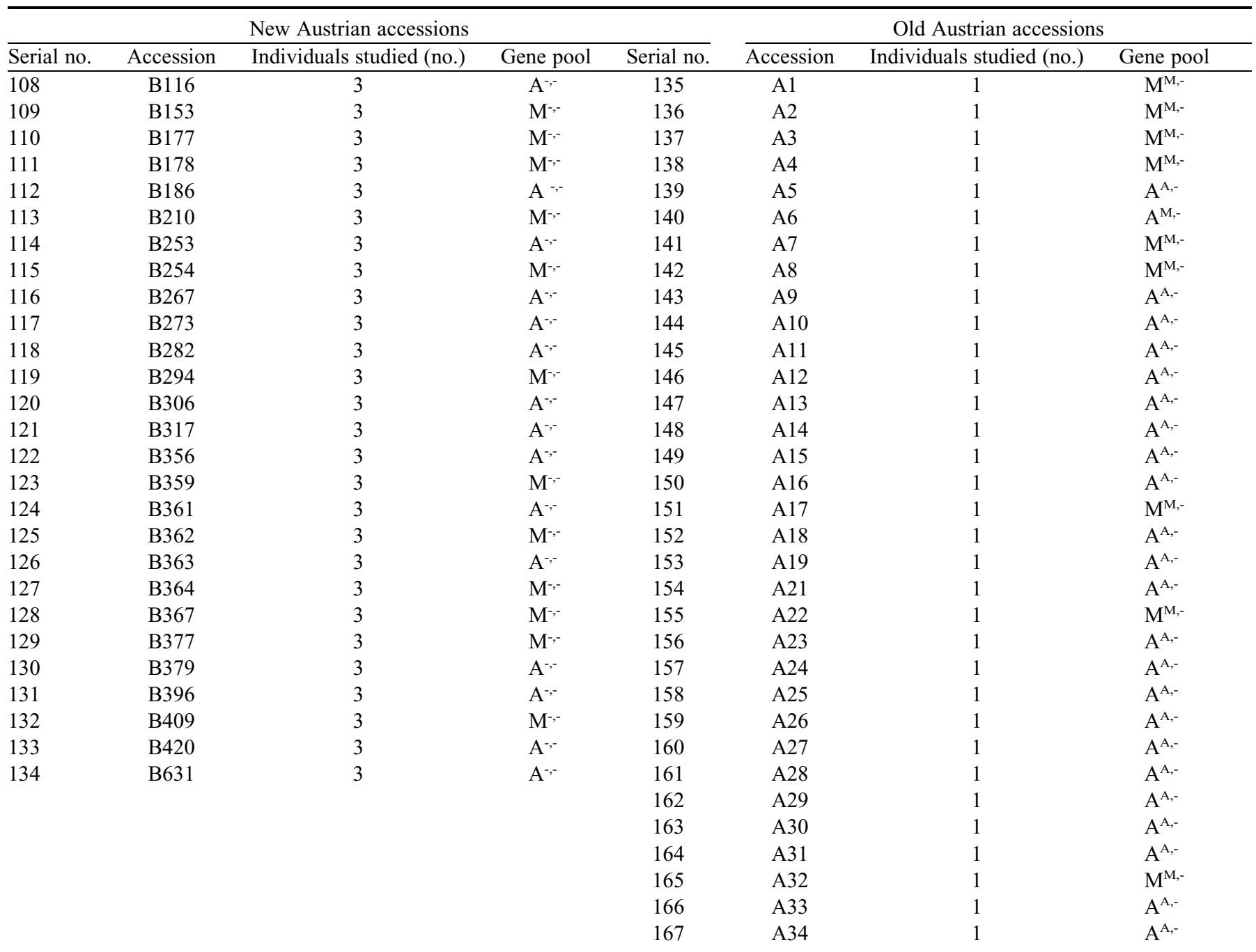

Information on gene pool of origin was acquired by the factorial correspondence analysis in the present study using Genetix 4.02 (Belkhir et al., 2001), whereas the two accompanying superscripts represent gene pool of origin as reported by Maras et al. (2006) and Šǔtar-Vozlič et al. (2006), respectively.

$\mathrm{M}=$ Mesoamerican gene pool; $\mathrm{A}=$ Andean gene pool.

With regard to the period of cultivation, more alleles (125) were found in both new groups than in both old groups of bean accessions (111). There were 36 alleles specific to the group of 85 modern accessions (277 individuals), whereas 22 alleles were detected only in the group of 82 old accessions (126 individuals) from Slovenia and Austria.

The AMOVA revealed that the molecular diversity was significantly different among all four groups of accessions (Table 3). It was shown that most of the molecular variation in the studied groups exists among accessions within groups (93\%) with lesser amounts among groups (7\%). It was confirmed, subsequently, that a between-group component of variation is statistically significant in all possible pairwise group comparisons and accounted for between $2.35 \%$ and $10.92 \%$ of total variation.

The within-group component of variation predominated also in the cases when AMOVA was used in the assessment of temporal (old and new) and geographical (Slovene and Austrian) group effect. Although highly significant, the between-variance component represented only $2.53 \%$ of the total temporal variation.
A much higher portion of the total geographical variation was accounted by the between-group component $(8.03 \%)$ indicating that the accessions are more differentiated as a function of their geographical origin than of their cultivation period.

Relationships among the individuals revealed by the FCA are presented in Figure 1. The first three components explained $12.6 \%$ of the total variation with $5.5 \%, 4.0 \%$, and $3.1 \%$ for the first, the second, and the third components, respectively. The FCA exhibits separation of individuals neither according to the geographical origin nor the period of cultivation. A striking pattern emerges from the FCA when the gene pool of origin of accessions, established in previous studies (Maras et al., 2006; Šuštar-Vozlič et al., 2006), is considered. Clear differentiation of accessions according to the gene pool of origin could be observed at the value -0.5 on the first axis. The dominating Andean gene pool consisted of 336 individuals representing 136 accessions (Fig. 1; Table 1). These included 53 new Slovene accessions (179 individuals), 44 old Slovene accessions (88 individuals), 15 new Austrian accessions (45 individuals), and 24 old Austrian accessions (24 individuals). The minor 


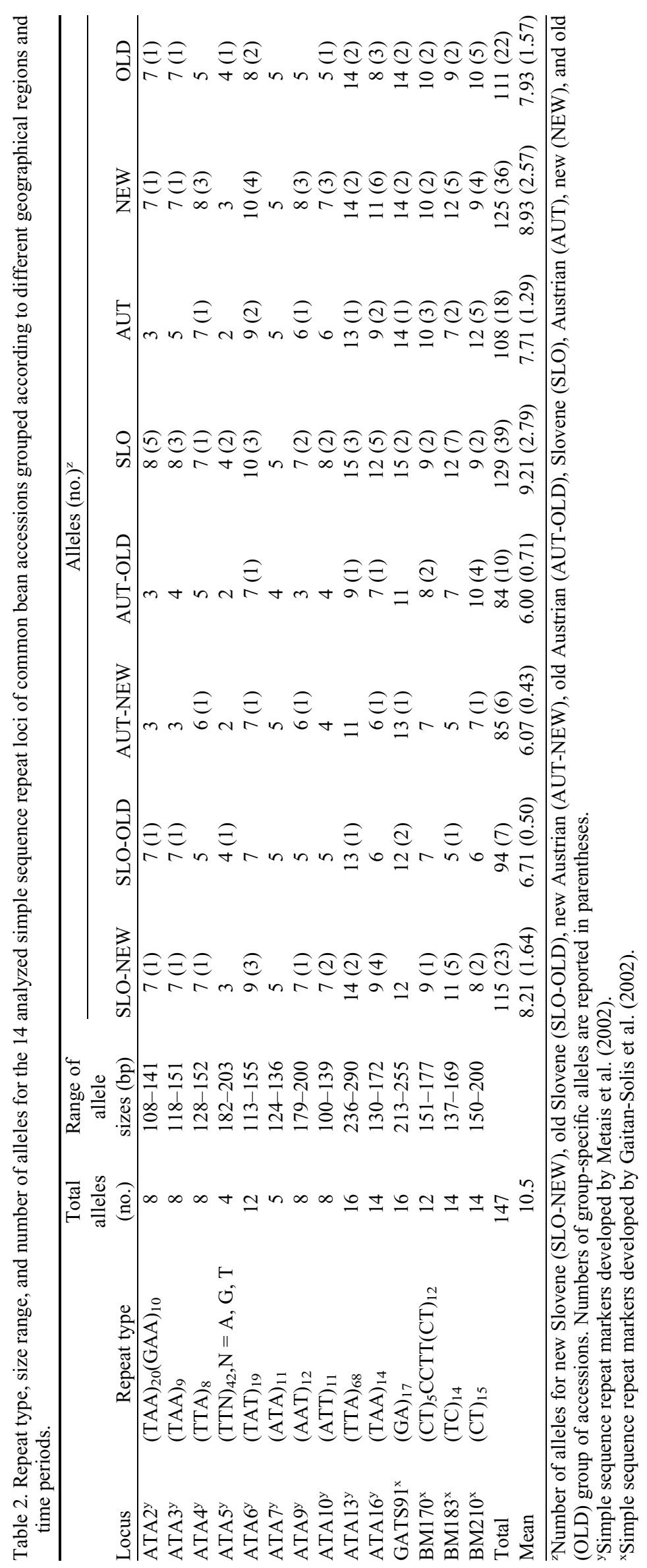


Mesoamerican gene pool contained 67 individuals representing 31 accessions (Fig. 1; Table 1). These included five new Slovene accessions (17 individuals), five old Slovene accessions (five individuals), 12 new Austrian accessions (36 individuals), and nine old Austrian accessions (nine individuals). Further supporting evidence for the existence of two gene pools in FCA came from the data on phaseolin type that were

Table 3. Results for the analysis of molecular variance for 167 common bean accessions cultivated in different time periods and geographical regions.

\begin{tabular}{lcccc}
\hline & \multicolumn{4}{c}{ Between-variance component $(\%)^{\mathrm{z}}$} \\
\cline { 2 - 5 } & SLO- & SLO- & AUT- & AUT- \\
& NEW & OLD & NEW & OLD \\
\hline SLO-NEW & & 2.35 & 10.15 & 9.70 \\
SLO-OLD & $* *$ & & 10.92 & 6.81 \\
AUT-NEW & $* *$ & $* *$ & & 6.60 \\
AUT-OLD & $* *$ & $* *$ & $* *$ & \\
Among all groups & 7.32 & $P<0.01$ & &
\end{tabular}

\begin{tabular}{lcc} 
Source & $\begin{array}{c}\text { Variance } \\
\text { component }\end{array}$ & $\begin{array}{c}\text { Variation } \\
\text { accounted (\%) }\end{array}$ \\
\hline Between temporal groups & 0.118 & $2.53^{* *}$ \\
Within temporal groups & 4.542 & 97.47 \\
Total & 4.660 & 100.00
\end{tabular}

\begin{tabular}{lcc} 
Source & $\begin{array}{c}\text { Variance } \\
\text { component }\end{array}$ & $\begin{array}{c}\text { Variation } \\
\text { accounted (\%) }\end{array}$ \\
\hline Between geographical groups & 0.387 & $8.03^{* *}$ \\
Within geographical groups & 4.436 & 91.97 \\
Total & 4.823 & 100.00
\end{tabular}

${ }^{\mathrm{z}} \mathrm{SLO}-\mathrm{NEW}=$ new Slovene accessions; SLO-OLD $=$ old Slovene accessions; AUT-NEW = new Austrian accessions; AUT-OLD = old Austrian accessions.

**Significant at $P<0.01$.

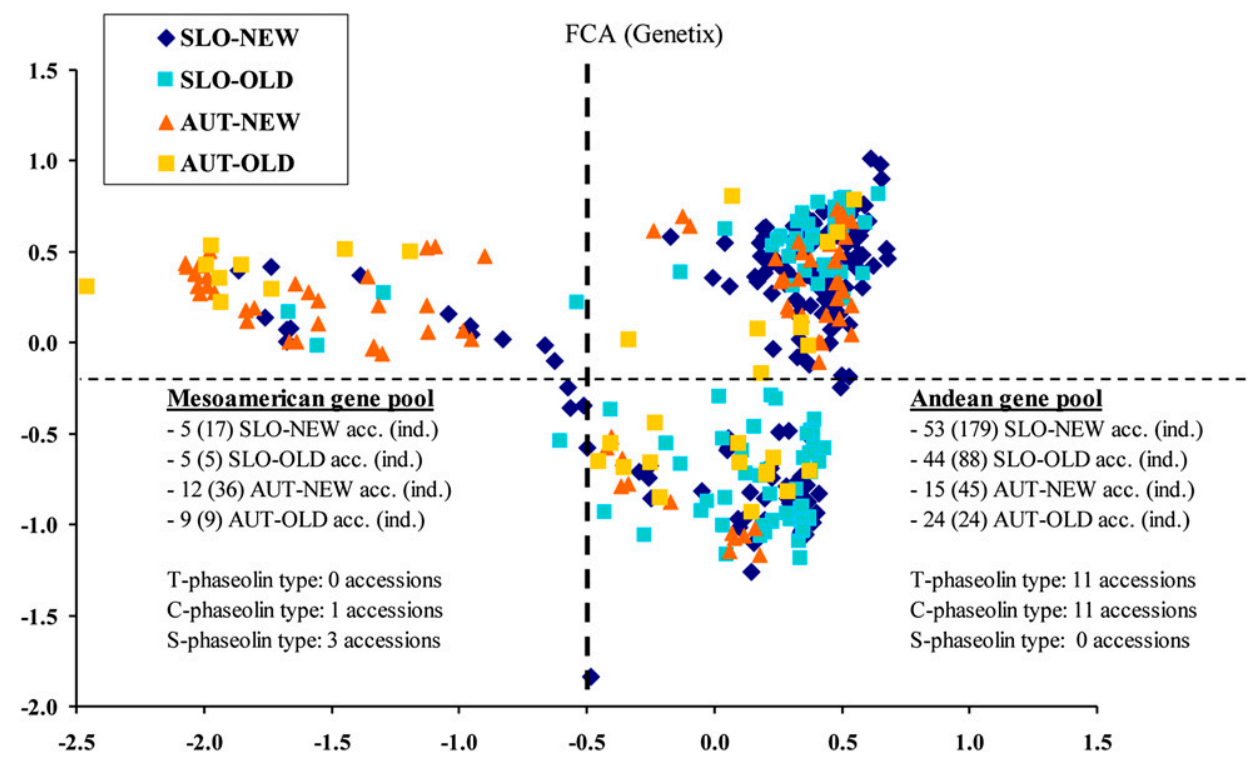

Fig. 1. Plot of the first two components derived from the factorial correspondence analysis in Genetix 4.02 (Belkhir et al., 2001) using simple sequence repeat data of 403 individuals (ind.) representing 167 common bean accessions (acc.). SLO-NEW = new Slovene accessions; SLO-OLD = old Slovene accessions; AUT-NEW = new Austrian accessions; AUT-OLD = old Austrian accessions. provided by Šuštar-Vozlič et al. (2006). The larger group included 22 accessions with C- and T-phaseolins, typical for Andean common bean germplasm, whereas the smaller group contained one accession of C-phaseolin and three accessions of S-phaseolin, which is most widely distributed among genotypes of Mesoamerican origin.

With regard to our previous studies (Maras et al., 2006; Šuštar-Vozlič et al., 2006), only few discrepancies were observed in the classification of 140 common accessions (322 individuals) into gene pools of origin. In the recent study, 121 accessions (291 individuals) were found in the Andean gene pool including one accession (A6), which was observed in the Mesoamerican gene pool in earlier reports (Table 1). Meanwhile, the Mesoamerican gene pool comprised 19 accessions (31 individuals) and hosted also two accessions (S7, S34), which belonged to the Andean gene pool in the previous reports (Table 1).

The classification of the accessions according to the gene pool of origin was further verified using a Bayesian modelbased clustering algorithm implemented in Structure. The two clusters detected in the Structure analysis corresponded to the two major gene pools (Fig. 2). A very clear population structure of the studied individuals (accessions) was observed because the majority of them showed $100 \%$ probability of membership to either of the two gene pools, Andean or Mesoamerican. The accession PHA452 showed a notable mixed population structure with one individual exhibiting 100\% Mesoamerican ancestry and other two individuals showing probability of Andean higher than $60 \%$. An admixed genetic background was detected also for several other accessions. Both FCA and Structure analysis suggest that hybrids of genotypes from a different gene pool of origin exist in the studied collections.

\section{Discussion}

Studies of the level and the structure of the genetic diversity of local cultivars of $P$. vulgaris are of fundamental importance, both for management of genetic resources and improvement of our understanding of the pathways of dissemination and the evolution of this species in Europe (Angioi et al., 2009). Although genetic diversity of common bean germplasm has been studied in detail in some European regions and countries (i.e., Spain, Portugal, and Italy), the information on collections from central and eastern Europe is poor.

One main goal of this research was to characterize global genetic diversity in a large set of bean accessions from two central European countries, Slovenia and Austria, and different time periods using SSR markers. A great deal of effort has already been put into characterizing genetic diversity of Slovene accessions using molecular and biochemical markers (Maras et al., 2006; Šuštar-Vozlič et al., 2006). Here attention is directed toward the Austrian bean germplasm and the 


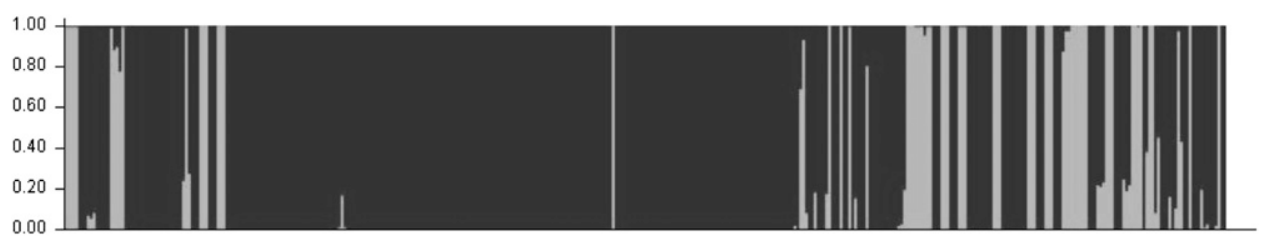

Fig. 2. Estimated population structure of 403 individuals representing 167 common bean accessions as revealed by Bayesian model-based cluster analysis in Structure 2.1 (Pritchard et al., 2000). Each individual is represented by a thin vertical line, which is partitioned into two colored segments that represent the individual estimated membership to the two clusters; black color represents Andean gene pool, whereas gray color indicates Mesoamerican gene pool.

relevance of newly acquired findings on modern Austrian accessions.

A total of 147 alleles were detected at 14 analyzed SSR loci with a mean of 10.5 alleles per locus in 167 accessions. This is comparable to the previous published reports, which affirmed SSRs as a very efficient tool in detecting DNA polymorphisms in common bean (Asfaw et al., 2009; Blair et al., 2006, 2009; Pérez-Vega et al., 2009). With respect to the data on allelic diversity, it is evident that a large variation of common bean existed in the past in the part of central Europe that embraces Austria and Slovenia and of which a great portion has been preserved until today.

Concerning different groups of accessions, the group of 58 new Slovene accessions predominates in group-specific alleles (23), whereas a set of 33 new Austrian beans contributed the lowest number of group-specific alleles (six). A notable shift in the frequency of several alleles was observed within Austrian beans. In the group of new accessions, 23 alleles were present that were not observed in a group of old accessions. The frequency of these alleles was not very high with only one exceeding 0.50 and another one 0.10 . There were 23 alleles that were not detected in the modern Austrian beans of which 18 had a frequency lower than 0.10 . This shift in allelic frequencies resulted in a relatively high Fst value (6.60) between two Austrian groups of accessions and was almost as high as the one calculated between the old Austrian and Slovene beans. At the same time, a rather low Fst value (2.35) was observed between the two Slovene groups. This indicates that the Austrian common bean germplasm has undergone a relatively strong diversification process in the last 200 years when compared with the Slovene germplasm. The discrepancy observed here could be explained in part by different ages and durations of cultivation of studied materials; other possible explanations are discussed later in the article.

AMOVA also revealed that both groups of new accessions exhibit the greatest differentiation against the accessions from other country regardless of the cultivation period. Apparently, in the last century, Austrian and Slovene beans have been diversifying through accumulation of different alleles building up distinct genetic structures. The evidence for this phenomenon comes also from the analysis of molecular variance calculated for the accessions grouped according to temporal and geographical criteria. Observation of low differentiation according to temporal parameters reflects the fact that a great part of the variation stored in the old accessions is comprised within the new accessions, whereas stronger differentiation of the accessions with respect to geographical criterion indicates that the genetic structure of the accessions from two countries has diverged substantially.
Many different factors must have contributed to increasing differentiation between the Austrian and Slovene germplasm. The strongest is probably the fact that the exchange of agricultural goods between the two regions slowed down after the collapse of Austro-Hungarian monarchy and formation of independent countries at the end of World War I. Commercial activities between the countries revived again only in the 1990s. Under the conditions of limited gene flow between the regions, evolution driven by various climatic conditions and diverse criteria of selection for morphoproductive characters used by farmers from different regions resulted in intensified diversification of the two germplasms. According to Zeven (1997), numerous introgressions and dissemination of new genotypes ever since the discovery of the American continent had a strong impact on the evolution of beans in Europe. Thus, introduction of genotypes from third countries could have further promoted the diversification of Austrian and Slovene bean.

With reference to the previous investigations of the origin of Slovene common bean (Maras et al., 2006; Šuštar-Vozlič et al., 2006), the clustering pattern in FCA was easily resolved. Two well-defined groups were observed in the FCA plot, a large Andean group with 136 accessions and a smaller Mesoamerican group with 31 accessions. The first group included 89.8\% of all old and $91.4 \%$ of all new Slovene accessions as well as $72.7 \%$ of all old and $55.6 \%$ of all new Austrian accessions. Solely C- and T-phaseolins were observed in the Andean cluster, whereas the Mesoamerican cluster contained three accessions with S-type and one accession with C-type. Further division of Andean accessions can be observed on a secondary axis of the FCA plot. In our previous studies, we described one of these subgroups within the Andean gene pool as a unique germplasm and potentially one of the secondary centers of common bean diversity in Europe (Šuštar-Vozlič et al., 2006). The present study shows that this germplasm was present in this region already 200 years ago. Furthermore, Maras (2007) showed that the accessions from this group resemble very well morphologically to Frutilla, an Andean bean genotype from Chile. All these findings suggest that these accessions represent a well-preserved genetic variability originating from South America, presumably from Chile, rather than a novel secondary center of genetic diversity.

The data clearly show that Andean genotypes have had a predominating role in the cultivation of common bean in Slovenia and Austria for centuries. It is evident that a low ratio of Mesoamerican genotypes in Slovenia has further declined in the last 60 years (from $10 \%$ to $8 \%$ ). On the contrary, its ratio advanced considerably in Austrian bean germplasm in the last two centuries (from $27 \%$ to $44 \%$ ). With respect to germplasm management, this is of great significance because genotypes from different gene pools complement each other in many important agroecological traits, including resistance to diseases and pests, growth habit, yield potential, and sensitivity to photoperiod, high temperatures, and moisture stress (Singh et al., 1991).

In a large survey of European bean accessions, Angioi et al. (2010) classified Austria together with Germany, France, the United Kingdom, and Sweden to the central-northern region 
characterized by a high incidence of Andean genotypes with Tphaseolin and a considerable proportion of Mesoamerican genotypes (29\%). This is in agreement with the findings of the present study, in which a high proportion (44\%) of Mesoamerican genotypes in Austrian germplasm was observed. In the same report, Angioi et al. (2010) classified Slovenia with southeastern European countries, where C-, T-, and S-phaseolins were observed in almost equal proportions. On the contrary, the findings of the current and our previous studies (Maras et al., 2006; Šuštar-Vozlič et al., 2006), in which a high occurrence of Andean genotypes with $\mathrm{C}$-phaseolin was revealed, clearly show that Slovenia belongs to the Mediterranean basin. Furthermore, the results indicate also that common bean was introduced into Slovenia primarily by western routes through Italy, where strong dominance of Andean genotypes has been reported for several regions (Angioi et al., 2009; Limongelli et al., 1996; Piergiovanni et al., 2000; Sicard et al., 2005). Different historical scripts and masterpieces indicate that common bean was part of the diet in Italy already in the early 16th century (Piergiovanni and Lioi, 2010). The earliest written evidence of common bean in Slovenia dates back to 1689 , when Valvasor (1689) described it as a very popular crop cultivated on a large scale inside Slovene territory. Early occurrence and rapid dissemination of common bean in Italy and Slovenia indicate that these two countries might have represented entering points for the first beans in Austria. They probably maintained this role until the beginning of the World War I and the collapse of the Habsburg Monarchy afterward, when the flux of beans among the three countries must have declined drastically. The results of the recent study suggest that Austria compensated this drop in trading activity by strengthening northern trading routes, which ultimately altered the genetic landscape of common bean and probably also of other crops.

Bayesian model-based cluster analysis confirmed the primary division of genotypes revealed by FCA. Genetic structure of the majority of the accession could be unambiguously assigned to one of the major gene pools. Structure analysis also indicated the existence of hybrids in Austrian and Slovene germplasm. These potential hybrids were observed also in FCA and were distributed in the plot between the two major gene pools. The existence of hybrids in Europe was first reported by Santalla et al. (2002), who found intermediate patterns of allozyme profiles in hybrids. Later, Rodino et al. (2006) showed that these genotypes possessed phaseolin typical of one gene pool and one or more morphological and allozyme traits of the other gene pool. Based on the analysis of six chloroplast SSRs and two nuclear loci of large number of European accessions, Angioi et al. (2010) suggested that a considerable proportion (44\%) of the European bean germplasm was derived from hybridization between the Andean and Mesoamerican gene pools. According to Rodino et al. (2006) and Santalla et al. (2002), hybrid genotypes gave rise to the secondary center of genetic diversity for common bean in Europe. They represent promising intergene pool crosses, which might facilitate broadening of the genetic base of cultivars and maximizing gains from selection for plant type, adaptation, yield, and resistance to high and low temperature, drought, pathogens, and low soil fertility (Singh, 2001).

\section{Literature Cited}

Angioi, S.A., D. Rau, G. Attene, L. Nanni, E. Bellucci, G. Logozzo, V. Negri, P.L. Spagnoletti Zeuli, and R. Papa. 2010. Beans in Europe: Origin and structure of the European landraces of Phaseolus vulgaris L. Theor. Appl. Genet. 121:829-843.
Angioi, S.A., D. Rau, M. Rodriguez, G. Logozzo, F. Desiderio, R. Papa, and G. Attene. 2009. Nuclear and chloroplast microsatellite diversity in Phaseolus vulgaris L. from Sardinia (Italy). Mol. Breed. 23:413-429.

Asfaw, A., M. Blair, and C. Almekinders. 2009. Genetic diversity and population structure of common bean (Phaseolus vulgaris L.) landraces from the East African highlands. Theor. Appl. Genet. 120:1-12.

Belkhir, K., P. Borsa, L. Chikhi, N. Raufaste, and F. Bonhomme. 2001. Genetix 4.02, logiciel sous Windows TM pour la génétique des populations. Laboratoire Genome, Populations, Interactions, Université de Montpellier II, Montpellier, France.

Blair, M.W., L.M. Díaz, H.F. Buendia, and M.C. Duque. 2009. Genetic diversity, seed size associations and population structure of a core collection of common beans (Phaseolus vulgaris L.). Theor. Appl. Genet. 119:955-973.

Blair, M.W., M.C. Giraldo, H.F. Buendia, E. Tovar, M.C. Duque, and S.E. Beebe. 2006. Microsatellite marker diversity in common bean (Phaseolus vulgaris L.). Theor. Appl. Genet. 113:100-109.

Blair, M.W., F. Pedraza, H.F. Buendia, E. Gaitan-Solis, S.E. Beebe, P. Gepts, and J. Tohme. 2003. Development of a genome-wide anchored microsatellite map for common bean (Phaseolus vulgaris L.). Theor. Appl. Genet. 107:1362-1374.

Gaitan-Solis, E., M.C. Duque, K.J. Edwards, and J. Tohme. 2002. Microsatellite repeats in common bean (Phaseolus vulgaris): Isolation, characterization, and cross-species amplification in Phaseolus ssp. Crop Sci. 42:2128-2136.

Gepts, P. and F.A. Bliss. 1988. Dissemination paths of common bean (Phaseolus vulgaris, Fabaceae) deduced from phaseolin electrophoretic variability. II. Europe and Africa. Econ. Bot. 42:86-104.

Gepts, P., T.C. Osborn, K. Rashka, and F.A. Bliss. 1986. Phaseolinprotein variability in wild forms and landraces of the common bean (Phaseolus vulgaris) -Evidence for multiple centers of domestication. Econ. Bot. 40:451-468.

Guinand, B. 1996. Use of a multivariate model using allele frequency distributions to analyze patterns of genetic differentiation among populations. Biol. J. Linn. Soc. Lond. 58:173-195.

Khairallah, M.M., B.B. Sears, and M.W. Adams. 1990. Mitochondrial restriction fragment length polymorphisms in wild Phaseolus vulgaris L.: Insights on the domestication of the common bean. Theor. Appl. Genet. 84:915-922.

Koenig, R. and P. Gepts. 1989. Allozyme diversity in wild Phaseolus vulgaris: Further evidence for two major centers of genetic diversity. Theor. Appl. Genet. 78:809-817.

Limongelli, G., G. Laghetti, P. Perrino, and A.R. Piergiovanni. 1996. Variation of seed storage proteins in landraces of common bean (Phaseolus vulgaris L.) from Basilicata, Southern Italy. Euphytica 92:393-399.

Lioi, L., A.R. Piergiovanni, D. Pignone, S. Puglisi, M. Santantonio, and G. Sonnante. 2005. Genetic diversity of some surviving on-farm Italian common bean (Phaseolus vulgaris L.) landraces. Plant Breed. 124:576-581.

Logozzo, G., R. Donnoli, L. Macaluso, R. Papa, H. Knupffer, and P.L. Spagnoletti Zeuli. 2007. Analysis of the contribution of Mesoamerican and Andean gene pools to European common bean (Phaseolus vulgaris L.) germplasm and strategies to establish a core collection. Genet. Resources Crop Evol. 54:1763-1779.

Maras, M. 2007. Morphological, biochemical and molecular characterization of Slovene common bean (Phaseolus vulgaris 1.) genetic resources. PhD diss., Univ. of Ljubljana, Ljubljana, Slovenia.

Maras, M., S. Sušnik, J. Šuštar-Vozlič, and V. Meglič. 2006. Temporal changes in genetic diversity of common bean (Phaseolus vulgaris L.) accessions cultivated between 1800 and 2000. Russ. J. Genet. 42:775-782.

Marotti, I., A. Bonetti, M. Minelli, P. Catizone, and G. Dinelli. 2007. Characterization of some Italian common bean (Phaseolus vulgaris L.) landraces by RAPD, semirandom and ISSR molecular markers. Genet. Resources Crop Evol. 54:175-188.

Metais, I., B. Hamon, R. Jalouzot, and D. Peltier. 2002. Structure and level of genetic diversity in various bean types evidenced with 
microsatellite markers isolated from a genomic enriched library. Theor. Appl. Genet. 104:1346-1352.

Ocampo, C.H., J.P. Martin, M.D. Sanchez-Yelamo, J.M. Ortiz, and O. Toro. 2005. Tracing the origin of Spanish common bean cultivars using biochemical and molecular markers. Genet. Resources Crop Evol. 52:33-40.

Peakall, R. and P.E. Smouse. 2006. GENALEX 6: Genetic analysis in Excel. Population genetic software for teaching and research. Mol. Ecol. Notes 6:288-295.

Pérez-Vega, E., A. Campa, L. De la Rosa, R. Giraldez, and J.J. Ferreira. 2009. Genetic diversity in a core collection established from the main bean genebank in Spain. Crop Sci. 49:1377-1386.

Piergiovanni, A.R. and L. Lioi. 2010. Italian common bean landraces: History, genetic diversity and seed quality. Diversity 2:837-862.

Piergiovanni, A.R., G. Taranto, and D. Pignone. 2000. Diversity among common bean populations from the Abruzzo region (Central Italy): A preliminary inquiry. Genet. Resources Crop Evol. 47:467470.

Pritchard, J.K., M. Stephens, and P. Donnelly. 2000. Inference of population structure using multilocus genotype data. Genetics 155:945-959.

Pritchard, J.K. and W. Wen. 2004. Documentation for STRUCTURE software. University of Chicago Press, Chicago, IL.

Rodino, P., M. Santalla, A.M. De Ron, and S.P. Singh. 2003. A core collection of common bean from the Iberian Peninsula. Euphytica 131:165-175.

Rodino, P., M. Santalla, A.M. González, A.M. De Ron, and S.P. Singh. 2006. Novel genetic variation in common bean from the Iberian Peninsula. Crop Sci. 46:2540-2546.

Santalla, M., A.M. De Ron, and M. De La Fuente. 2010. Integration of genome and phenotypic scanning gives evidence of genetic structure in Mesoamerican common bean (Phaseolus vulgaris L.) landraces from the southwest of Europe. Theor. Appl. Genet. 120:1635-1651.

Santalla, M., P. Rodino, and A.M. De Ron. 2002. Allozyme evidence supporting southwestern Europe as a secondary center of genetic diversity for the common bean. Theor. Appl. Genet. 104:934-944.

Sicard, D., L. Nanni, O. Porfiri, D. Bulfon, and R. Papa. 2005. Genetic diversity of Phaseolus vulgaris L. and P. coccineus L. landraces in central Italy. Plant Breed. 124:464-472.

Singh, S.P. 2001. Broadening the genetic base of common bean cultivars: A review. Crop Sci. 41:1659-1675.

Singh, S.P., P. Gepts, and D.G. Debouck. 1991. Races of common bean (Phaseolus vulgaris, Fabaceae). Econ. Bot. 45:379-396.

Šuštar-Vozlič, J., M. Maras, B. Javornik, and V. Meglič. 2006. Genetic diversity and origin of Slovene common bean (Phaseolus vulgaris L.) germplasm as revealed by AFLP markers and phaseolin analysis. J. Amer. Soc. Hort. Sci. 131:242-249.

Svetleva, D., G. Pereira, J. Carlier, L. Cabrita, J. Leitao, and D. Genchev. 2006. Molecular characterization of Phaseolus vulgaris L genotypes included in bulgarian collection by ISSR and AFLP analyses. Sci. Hort. 109:198-206.

Valvasor, J.V. 1689. Die Ehre dess Hertzogthums Crain. Reprinted in 1978. Mladinska knjiga, Ljubljana, Slovenia.

Yu, K., S.J. Park, V. Poysa, and P. Gepts. 2000. Integration of simple sequence repeat (SSR) markers into a molecular linkage map of common bean (Phaseolus vulgaris L.). J. Hered. 91:429-434.

Yu, K.F., S.J. Park, and V. Poysa. 1999. Abundance and variation of microsatellite DNA sequences in beans (Phaseolus and Vigna). Genome 42:27-34.

Zeven, A.C. 1997. The introduction of the common bean (Phaseolus vulgaris L.) into Western Europe and the phenotypic variation of dry beans collected in the Netherlands in 1946. Euphytica 94:319-328. 